(Amdrup and Jensen, 1970), and proximal gastric vagotomy (J. de Miguel, personal communication, 1971). Its effect is to reduce acid production as much as does truncal vagotomy, but to leave the emptying mechanism of the stomach unimpaired, which has the great advantage, as Johnston and Wilkinson (1970) and Amdrup and Jensen (1970) first pointed out, that no accompanying gastric drainage operation is required. During the past two and a half years more than 120 cases of duodenal ulcer have been treated by highly selective vagotomy in Leeds without drainage. Our results to date havc been most encouraging, with no operative mortality, no gastric retention, no proved recurrent ulceration, no significant diarrhoea, and high Visick gradings, but obviously longer follow-up studies will be required before a decision can be reached concerning the proper value of this operation in the management of duodenal ulcer.

We should like to express our thanks to the following for their help in the conduct of this study: Mr. F. T. de Dombal, for statistical advice; Mrs. R. Nicholson, Mrs. M. A. Pybus, and Miss E. Bartholomew for secretarial services; Mrs. I. Dent for help in tracing patients; and the Board of Governors of the United Leeds Hospitals and the York Peptic Ulcer Research Trust for grants to defray some of the costs of the investigation.

\section{References}

Amdrup, E., and Jensen, H. E. (1970). Gastroenterology, 59, 522. Aurge, H. (1964). Vagotomy. London, Butterworth.
Clark, C. G., and Murray, J. G. (1963). Fournal of the Royal College of Surgeons of Edinburgh, 8, 212.

Cox, A. G., and Cooke, W. M. (1970). British Medical Fournal, 1, 432.

Fawcett, A. N., Johnston, D., and Duthie, H. L. (1969). British Fournal of

Surgery, 56, 111 .
Frimer, M. L., Cohen, M. M., Harrison, R. C., and Holubitsky, I. B. (1970). Gut, 11, 881.

Gillespie, G., Elder, J. B., Gillespie, I. E., Kay, A. W., and Campbell, E. H. G. (1970). Gastroenterology, 58, 625.

Goligher, J. C., Pulvertaft, C. N., and Watkinson, G. (1964). British Medical fournal, 1, 455.

Goligher, J. C., Pulvertaft, C. N., and Franz, R. C. (1966). In Conference on Postgraduate Gastroenterology, ed. T. J. Thomson and I. E. Gillespie. Chapt. 26. London, Baillière, Tindall \& Cassell.

Goligher, J. C., et al. (1968a). British Medical fournal, 2, 781.

Goligher, J. C., et al. (1968b). British Medical fournal, 2, 787.

Grassi, G. (1971). British Fournal of Surgery, 58, 187.

Hollander, F. (1948). Gastroenterology, 11, 419.

Holle, F. (1967). Archiv für klinische Chirurgie, 319, 233.

Holt, R. L., and Lythgoe, J. P. (1965). British fournal of Surgery, 52, 27.

Johnston, D., Thomas, D. G., Checketts, R. G., and Duthie, H. L. (1967). British fournal of Surgery, 54, 831

Johnston, D., and Wilkinson, A. R. (1970). British fournal of Surgery, 57, 289.

Jordan, P. H., jun., and Condon, R. E. (1970). Annals of Surgery, 172, 547.

Kennedy, T., and Connell, A. M. (1969). Lancet, 1, 899.

Kennedy, T., and Connell, A. M. (1970). Lancet, 1, 675.

Kronborg, O., Malmström, J., and Christiansen, P. M. (1970). Scandinavian fournal of Gastroenterology, 5, 519.

Lee, M. (1969). British fournal of Surgery, 56, 10.

Mason, M. C., and Giles, G. R. (1968). British fournal of Surgery, 55, 865.

Mason, M. C., and Giles, G. R. (1969). British Fournal of Surgery, 56, 384.

Pulvertaft, C. N., and Cox, A. G. (1969). In After Vagotomy, ed. J. A. Williams and A. G. Cox, p. 150. London, Butterworth.

Schofield, P. F., Watson-Williams, E. J., and Sorrell, V. F. (1967). Archives of Surgery, 95, 615.

Visick, A. H. (1948). Annals of the Royal College of Surgeons of England, 3, 266.

Watkin, D. F. L., and Hudson, J. C. (1971). Paper given at the Surgical Research Society, July 1971.

Weinberg, J. T. A., Stempien, S. J., Movius, H. J., and Dagradi, A. E. (1956). American fournal of Surgery, 92, 202.

\title{
Prediction of Hypothyroidism after Partial Thyroidectomy for Thyrotoxicosis
}

\author{
W. MICHIE, C. A. S. PEGG, P. D. BEWSHER
}

Though a reasonable prediction of the incidence of hypothyroidism can be made for a group of patients on the basis of remnant size, the fate of the individual can be predicted only within very wide limits. An indication of the future status of the individual patient at one year and subsequently does, however, seem possible from serum protein-bound iodine estimations at one and four months after operation. Hypothyroidism developing later than one year after operation has not been observed in this series. The ability to assess thyroid status early after surgery is of some merit in the long-term supervision of the postoperative thyrotoxic patient, and in this respect surgical treatment seems to have some advantage over radioiodine therapy. to be an association between the incidence of hypothyroidism and the presence of antithyroglobulin antibodies, but this association was not statistically significant. The data suggested that blood group $O$ might be more common and blood group $A$ less common in hypothyroid patients. The incidence of hypothyroidism seemed to be uninfluenced by the age or sex of the patient, the size of the gland, or the amount and duration of preoperative antithyroid drug therapy.

Joint Thyroid Clinic, Royal Infirmary and Medical School, Aberdeen AB9 2ZB

W. MICHIE, P.R.C.s.ED., Consultant Surgeon

C. A. S. PEGG, CH.M., F.R.C.S., Senior Registra

P. B. BEWSHER, M.D., M.R.c.P.ED., Senior Lecturer

\section{Introduction}

The plurality of treatment of the thyrotoxic patient is an indication that none of the methods available is wholly acceptable. Hypothyroidism constitutes the major complication. After radioiodine therapy it is consequent on the biological effect of ionizing radiation on the replicative mechanism of the thyroid follicular cell (Greig, 1965). An incidence of $70 \%$ hypothyroidism 10 years after ${ }^{181}$ I therapy has been estimated (Nofal et al., 1966), and since the process of interference with cell reproduction is a continuing one it is possible that 
nearly all patients treated by radioiodine may eventually become hypothyroid. The reported incidence of hypothyroidism after partial thyroidectomy ranges from 3.5 to $35 \%$ in this country (Riddell, 1962; Hedley et al., 1970a) and 4.5 to $48 \%$ in the United States (Cattell, 1949; Beahrs and Sakulsky, 1968), but the higher figures may merely represent more critical evaluation of postoperative thyroid status.

Though the behaviour of a group of patients after surgery is known, the metabolic future of the individual patient is unpredictable. In this paper we seek to examine some factors, both for the group and in the individual patient, which might influence the development of hypothyroidism after surgery and be of value in its early diagnosis and subsequent management: (1) in preoperative assessment and preparation, (2) surgical considerations, and (3) in early postoperative behaviour.

\section{Patients and Methods}

We have studied 278 patients ( 235 female and 43 male) treated by partial thyroidectomy for primary thyrotoxicosis and toxic nodular goitre during 1965-9 inclusive. The diagnosis was based on the clinical diagnostic index of Crooks et al. (1959) and serum protein-bound iodine (P.B. ${ }^{127} \mathrm{I}$ ) estimations (normal range for our laboratory 4-8 $\mu \mathrm{g} / 100 \mathrm{ml}$ ), and confirmed by a radioactive tracer test supplemented where necessary by the response to triiodothyronine (Hobbs et al., 1963). Hypothyroidism was assessed by clinical examination based on the standard diagnostic index described by Billewicz et al. (1969), on electrocardiographic evidence, and on serial serum P.B. ${ }^{127}$ I and cholesterol estimations. The final arbiter was a therapeutic trial with thyroxine (Werner and Spooner, 1955). Patients were examined at one, four, and twelve months after operation and thereafter on a yearly basis until the services of a computer-assisted register became available (Hedley et al., 1970b).

Details of antithyroid drug therapy were kept for each patient, both for the duration of treatment and for the amount prescribed. Records of blood groups were available for 123 patients and of antithyroid antibody titres for 191 patients. Antibody to thyroglobulin was determined by the tanned red cell test of Fulthorpe et al. (1961) and the anticytoplasmic antibody by the fluorescent antibody test of Beck (1971). Operative details included weight of resected thyroid tissue and an estimate of remnant weight. During the first two years of the study the number of patients requiring thyroxine replacement was high and a change of policy towards leaving larger remnants was adopted in the latter half of 1967. This provided an opportunity to examine the influence of remnant size on subsequent hypothyroidism.

\section{Results}

Thyroxine replacement therapy was given to 137 patients, an incidence of hypothyroidism of $49 \%$. The sex distribution was the same in euthyroid and hypothyroid patients. Four patients developed recurrent thyrotoxicosis but for the purpose of this paper they have been included in the euthyroid group. With one possible exception hypothyroidism was confirmed in all patients on clinical and biochemical evidence within 12 months of operation. The exception had subnormal P.B. ${ }^{127} I$ results at one and four months but thereafter the P.B. ${ }^{127} I$ levels were borderline. However, neither clinical nor electrocardiographic evidence of hypothyroidism was seen until three years after operation, at which time replacement therapy was started. In the latter part of the study it was our policy to give thyroxine replacement therapy where indicated, at the end of one year.

\section{PREOPERATIVE ASSESSMENT AND PREPARATION}

Age.-The ages of the patients varied from 16 to 65 years. The incidence of hypothyroidism shows no trend with age of the patient at the time of operation (Table I) and though $71 \%$ of the patients of 61 years or more became hypothyroid, the numbers are too small to be meaningful.

TABLE 1-Postoperative Hypothyroidism in Relation to the Age of Patient at Time of Operation

\begin{tabular}{|c|c|c|c|c|c|c|c|}
\hline \multirow{2}{*}{ Patients } & \multicolumn{6}{|c|}{ Age in Years } & \multirow{2}{*}{$\begin{array}{l}\text { Total } \\
\text { No. }\end{array}$} \\
\hline & $16-20$ & $21-30$ & $31-40$ & $41-50$ & $51-60$ & $61-65$ & \\
\hline $\begin{array}{l}\text { Euthyroid } \\
\text { Hypothyroid }\end{array}$ & $\begin{array}{r}9 \\
10\end{array}$ & $\begin{array}{l}36 \\
24\end{array}$ & $\begin{array}{l}47 \\
39\end{array}$ & $\begin{array}{l}35 \\
46\end{array}$ & $\begin{array}{l}12 \\
13\end{array}$ & $\begin{array}{l}2 \\
5\end{array}$ & $\begin{array}{l}141 \\
137\end{array}$ \\
\hline \%Hypothyroid & 53 & 40 & 45 & 57 & 52 & 71 & 49 \\
\hline
\end{tabular}

Blood Group.-Records are available for 123 patients; in these the incidence of $O$ and $A$ blood groups is identical with the general population in the north-east of Scotland (Mourant et al., 1958) (Table II). Group O was slightly more common in hypothyroid $(P<0.1)$ than in euthyroid patients and group $A$ less common $(P=0.05)$ (Table III).

TABLE II-Comparison of ABO Blood 'Groups (\%) of General Population of N.E. Scotland with Thyrotoxic Patients in Present Survey

\begin{tabular}{|c|c|c|c|c|}
\hline Blood Group: & o & $\mathbf{A}$ & B & $\mathbf{A B}$ \\
\hline $\begin{array}{l}\text { N.E. Scotland... } \\
\text { Thyrotoxic patients }\end{array}$ & $\begin{array}{l}51 \cdot 16 \\
51 \cdot 22\end{array}$ & $\begin{array}{l}35 \cdot 37 \\
35 \cdot 77\end{array}$ & $\begin{array}{r}10.59 \\
9.76\end{array}$ & $\begin{array}{l}2 \cdot 87 \\
3 \cdot 24\end{array}$ \\
\hline
\end{tabular}

TABLE III-Incidence of ABO Blood Groups in Euthyroid and Hypothyroid Patients after Surgery

\begin{tabular}{c|c|c|c|c|c}
\hline Blood Group: & O & A & B & AB & Total No. \\
\hline Euthyroid patients.. & 22 & 25 & 6 & 2 & 55 \\
Hypothyroid patients & 41 & 19 & 6 & 2 & 68 \\
\hline
\end{tabular}

Antithyroid Drugs. - The choice of antithyroid drugs and the duration of therapy were determined by the individual physicians who supervised the preoperative care of the patients. Both carbimazole and methylthiouracil were used, the former in 205 patients and the latter in 67. Six received both drugs at different times. To effect a crude comparison carbimazole was regarded as being 10 times more potent than methylthiouracil, and the prescribed doses of both drugs are given in terms of carbimazole. Though a record of the prescribed dose was kept, no attempt was made to verify that the patient had always taken the recommended dose. Neither the amount of antithyroid drugs prescribed nor the duration of therapy affected the incidence of hypothyroidism (Tables IV and V).

Antithyroid Antibody Tests.-Details of antithyroid antibody tests carried out preoperatively are available for 191 patients. Results of both tests were graded as negative, positive, and strongly positive (Table VI). Antithyroglobulin (tanned red cell) antibody (positive and strongly positive) was more prevalent in hypothyroid than in euthyroid patients, though this difference is not statistically significant $(P<0 \cdot 1)$. Before operation $33(17 \%)$ of 191 patients had a positive tanned red cell

TABLE IV-Incidence of Hypothyroidism in Relation to Total Amount of Antithyroid Drugs Prescribed

\begin{tabular}{|c|c|c|c|c|c|c|c|}
\hline \multirow{2}{*}{ Patients } & \multicolumn{6}{|c|}{ Dose (g) } & \multirow{2}{*}{$\begin{array}{l}\text { Total } \\
\text { No. }\end{array}$} \\
\hline & $1-2$ & $2-3$ & $3-4$ & $4-6$ & $6-10$ & $>10$ & \\
\hline $\begin{array}{l}\text { Euthyroid :.d } \\
\text { Hypothyroid }\end{array}$ & $\begin{array}{l}32 \\
32\end{array}$ & $\begin{array}{l}37 \\
28\end{array}$ & $\begin{array}{l}26 \\
23\end{array}$ & $\begin{array}{l}17 \\
22\end{array}$ & 11 & $\begin{array}{l}18 \\
15\end{array}$ & $\begin{array}{l}141 \\
137\end{array}$ \\
\hline \%Hypothyroid & 50 & 43 & 47 & 56 & 61 & 45 & 49 \\
\hline
\end{tabular}


TABLE VI-Relationship between Antithyroid Antibodies Determined before Operation and Incidence of Hypothyroidism

\begin{tabular}{|c|c|c|c|c|c|c|c|c|}
\hline & \multirow{3}{*}{ Patients } & & \multicolumn{3}{|c|}{ Tanned Red Cell } & \multicolumn{3}{|c|}{ Anticytoplasmic Antibody } \\
\hline & & & \multirow{2}{*}{$\frac{\text { Neg. }}{0-1 / 25}$} & \multirow{2}{*}{$\begin{array}{c}\text { Pos. } \\
1 / 250-1 / 2,500\end{array}$} & \multirow{2}{*}{\begin{tabular}{|c|} 
Strongly Pos. \\
$1 / 25,000-1 / 2,500,000$
\end{tabular}} & \multirow{2}{*}{$\frac{\text { Neg. }}{0 \pm}$} & \multirow{2}{*}{$\frac{\text { Pos. }}{+}$} & Strongly Pos. \\
\hline & & & & & & & & $++\quad-1++$ \\
\hline $\begin{array}{l}\text { Euthyroid } \\
\text { Hypothyroid }\end{array}$ & 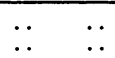 & $\begin{array}{l}\ldots \\
\cdots\end{array}$ & $\begin{array}{l}83 \\
75\end{array}$ & $\begin{array}{l}5 \\
6\end{array}$ & $\begin{array}{r}6 \\
16\end{array}$ & $\begin{array}{l}33 \\
33\end{array}$ & $\begin{array}{l}18 \\
15\end{array}$ & $\begin{array}{l}43 \\
49\end{array}$ \\
\hline
\end{tabular}

TABLE V-Incidence of Hypothyroidism in Relation to Duration of Antithyroid Drug Therapy

\begin{tabular}{|c|c|c|c|c|c|c|c|c|c|}
\hline \multirow{2}{*}{\multicolumn{2}{|c|}{ Patients }} & \multicolumn{7}{|c|}{ Duration (Months) } & \multirow{2}{*}{$\begin{array}{l}\text { Total } \\
\text { No. }\end{array}$} \\
\hline & & $0-1$ & $1-2$ & $2-3$ & $3-6$ & $6-12$ & $12-24$ & 24-72 & \\
\hline $\begin{array}{l}\text { Euthyroid } \\
\text { Hypothyroid }\end{array}$ & 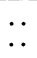 & $\begin{array}{l}7 \\
4\end{array}$ & $\begin{array}{l}39 \\
24\end{array}$ & $\begin{array}{l}35 \\
36\end{array}$ & $\begin{array}{l}23 \\
31\end{array}$ & $\begin{array}{l}17 \\
21\end{array}$ & 12 & $\begin{array}{l}8 \\
9\end{array}$ & $\begin{array}{l}141 \\
137\end{array}$ \\
\hline \%Hypothyroid & .. & 36 & 38 & 51 & 57 & 55 & 50 & 53 & 49 \\
\hline
\end{tabular}

titre; after operation 22 of these became hypothyroid while 11 remained euthyroid. Positive anticytoplasmic antibody was found in $125(66 \%)$ of the 191 patients. In contrast to the tanned red cell results anticytoplasmic antibody was equally prevalent in hypothyroid (51\%) and euthyroid (49\%) patients.

\section{SURGICAL CONSIDERATIONS}

All patients were operated on in the same surgical unit and a standard pattern of procedure and assessment was used.

Remnant Weight.-As reported elsewhere (Hedley et al., 1971) estimates of remnant weight in individual patients show considerable variation; the standard deviations of the estimates were as high as $25 \%$ of the true weight in a cadaver study. But even with this variation it can be seen that the incidence of hypothyroidism decreased significantly as remnant size increased $(P<0.001)$ (Table VII).

Total gland mass was calculated from the estimated remnant weight plus the weight of the resected thyroid specimen. Six glands were less than $20 \mathrm{~g}$, and 33 were $100 \mathrm{~g}$ or more. The average gland mass for hypothyroid patients was $55 \mathrm{~g}$, for euthyroid patients $60 \mathrm{~g}$, and for the series as a whole $57 \mathrm{~g}$. The incidence of hypothyroidism in relation to total gland mass is shown in Table VIII. Since remnant size has a pronounced effect on the incidence of hypothyroidism, we have examined the data for total gland mass, controlled for remnant weight (Fig. 1). It can be seen that for any given remnant weight the total gland mass does not differ between euthyroid and hypothyroid patients. Fig. 2 shows that, for the same gland weight, the thyroid remnant was consistently smaller for patients who became hypothyroid. Fig. 1 also shows that remnant size tended to increase with increasing total gland

TABLE VII-Incidence of Hypothyroidism in Relation to Estimated Weight of Thyroid Remnant

\begin{tabular}{ll|c|c|c|c|c}
\hline \multirow{2}{*}{ Patients } & & \multicolumn{3}{|c|}{ Remnant Weight (g) } & Total \\
\cline { 3 - 6 } & & $2-4$ & $5-7$ & $8-10$ & $>10$ & \\
\hline \begin{tabular}{ll|c|c|c} 
Euthyroid \\
Hypothyroid
\end{tabular} & $\cdots$ & 40 & 48 & 42 & 11 & 141 \\
\hline \% Hypothyroid & $\ldots$ & 77 & 39 & 18 & 3 & 137 \\
\hline
\end{tabular}

TABLE VIII-Incidence of Hypothyroidism in Relation to Total Gland Mass

\begin{tabular}{rl|c|c|c|c|c|c}
\hline \multirow{2}{*}{ Patients } & & \multicolumn{5}{c|}{ Weight (g) } & Total \\
\cline { 3 - 7 } & & $10-29$ & $30-49$ & $50-69$ & $70-99$ & $>100$ & No. \\
\hline Euthyroid .. &.. & 24 & 36 & 35 & 27 & 19 & 141 \\
Hypothyroid.. &.. & 20 & 57 & 34 & 12 & 14 & 137 \\
\hline \% Hypothyroid &.. & 45 & 61 & 49 & 31 & 42 & 49 \\
\hline
\end{tabular}

weight. The increase, however, was only slight (about $60 \%$ ) for a fivefold increase in gland weight.

As indicated earlier the high hypothyroid rate found during 1965-6 dictated a policy of leaving larger remnants. This led to a reduction in the incidence of hypothyroidism $(P<0.02)$ during the last three years of the study (Table IX).

TABLE IX-Incidence of Hypothyroidism in Relation to Mean Estimated Remnant Weight for Each Year from 1965 to 1969

\begin{tabular}{|c|c|c|c|c|c|c|}
\hline \multirow{3}{*}{ Patients } & 1965 & 1966 & 1967 & 1968 & 1969 & \multirow{3}{*}{$\begin{array}{l}\text { Total } \\
\text { No. }\end{array}$} \\
\hline & \multicolumn{5}{|c|}{ Mean Estimated Weight (g) } & \\
\hline & $3 \cdot 5$ & $4 \cdot 0$ & $5 \cdot 7$ & $8 \cdot 0$ & $9 \cdot 0$ & \\
\hline $\begin{array}{l}\text { Euthyroid } . . \\
\text { Hypothyroid.. }\end{array}$ & $\begin{array}{l}18 \\
30\end{array}$ & $\begin{array}{l}19 \\
51\end{array}$ & $\begin{array}{l}38 \\
25\end{array}$ & $\begin{array}{l}37 \\
21\end{array}$ & $\begin{array}{l}29 \\
10\end{array}$ & $\begin{array}{l}141 \\
137\end{array}$ \\
\hline \% Hypothyroidism.. & 63 & 73 & 40 & 36 & 26 & 49 \\
\hline
\end{tabular}

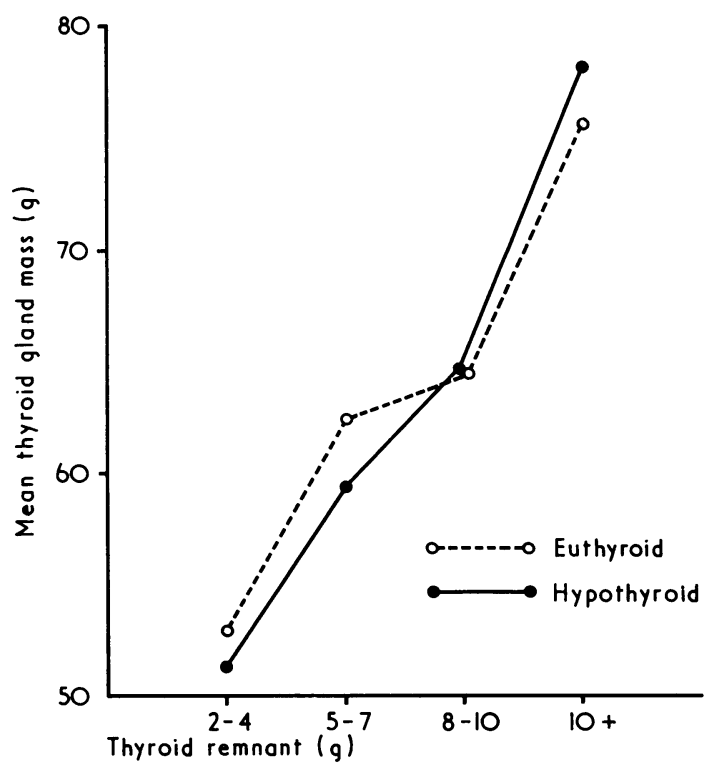

FIG. 1-Comparison of total gland mass in hypothyroid and euthyroid patients, standardized for remnant weight.

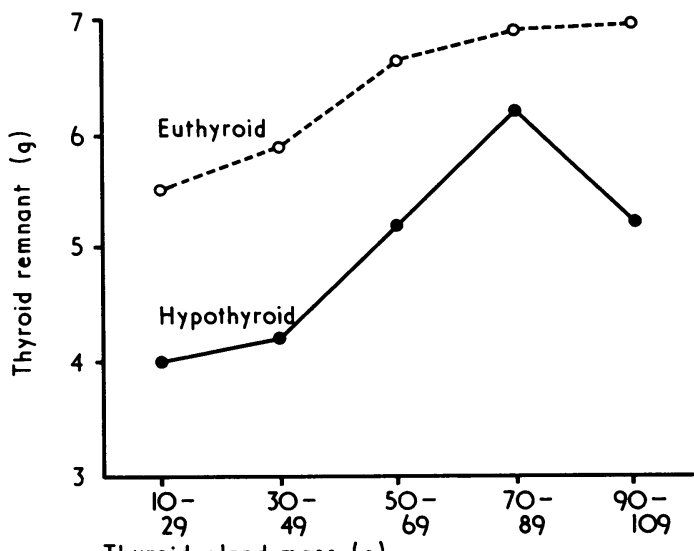

Thyroid gland mass (g)

FIG. 2-Comparison of remnant weights in hypothyroid and euthyroid patients, standardized for total gland mass. 


\section{DETECTION OF POSTOPERATIVE HYPOTHYROIDISM}

The serum P.B. ${ }^{127}$ I levels at one and four months after operation may give a good indication of the patient's thyroid status at one year and later (Table X). Details are available for 275 patients in the series. When both values were $4 \mu \mathrm{g} / 100 \mathrm{ml}$ or greater hypothyroidism did not occur; when both were below $4 \mu \mathrm{g} / 100 \mathrm{ml}$ thyroxine replacement was considered necessary in $75 \%$. Of 27 patients who had a subnormal P.B. ${ }^{127} \mathrm{I}$ at one month and a normal value at four months only two

TABLE X-Incidence of Hypothyroidism in Relation to P.B. ${ }^{127} I$ Levels at One and Four Months after Operation

\begin{tabular}{|c|c|c|c|c|c|c|c|}
\hline \multicolumn{3}{|c|}{$\begin{array}{l}\text { Level at } 1 \text { month }(\mu \mathrm{g} / 100 \mathrm{ml}) \\
\text { Level at } 4 \text { months }(\mu \mathrm{g} / 100 \mathrm{ml})\end{array}$} & \multirow{2}{*}{$\begin{array}{r}<4 \\
<4 \\
42 \\
128\end{array}$} & \multirow{2}{*}{$\begin{array}{c}\geqslant 4 \\
<4 \\
9 \\
6\end{array}$} & \multirow{2}{*}{$\begin{array}{r}<4 \\
\geqslant 4 \\
25 \\
2\end{array}$} & \multirow{2}{*}{ 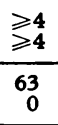 } & \multirow{2}{*}{$\begin{array}{c}\text { Total } \\
\text { No. }\end{array}$} \\
\hline $\begin{array}{l}\text { Euthyroid patients } \\
\text { Hypothyroid patients }\end{array}$ & 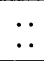 & $\therefore$ & & & & & \\
\hline$\%$ Hypothyroid. . & .. & .. & 75 & 40 & 7 & 0 & 49 \\
\hline
\end{tabular}

Data for 3 patients incomplete.

(7\%) were on replacement therapy at one year and subsequently. This apparent improvement within the first year might suggest that of the 170 patients with low P.B. ${ }^{127}$ I levels at one and four months postoperatively, a greater proportion than $25 \%$ might have become euthyroid at one year if replacement therapy had been withheld. Twenty-one patients operated on during 1965-6, whose P.B. ${ }^{127}$ I values were less than $4 \mu \mathrm{g} / 100 \mathrm{ml}$ at one, four, and at twelve months after operation, were kept under observation for a further year. None showed clinical improvement and replacement therapy was started at two years. In the light of this experience we would emphasize that in none of the 128 patients with low P.B. ${ }^{127}$ I levels at one and four months after operation who were given thyroxine was it considered justifiable to withhold replacement therapy.

\section{Discussion}

Review of the results shows that the most significant aetiological factor in postoperative hypothyroidism is small remnant size. Not only does the association between small remnant size and hypothyroidism hold for the series as a whole but it is also seen in the annual incidence of hypothyroidism during the individual years from 1965 to 1969 when the policy of increasing the remnant size is taken into account. But large remnant size per se will not necessarily abolish hypothyroidism; for patients with a remnant size in the range of 8 to $10 \mathrm{~g}$ the hypothyroid rate was $30 \%$ (Table VII).

The larger remnant also introduces the possible hazard of thyrotoxic recurrence. Crile and McCullagh (1951), Painter (1960), and Wilson (1967) observed that the incidence of hypothyroidism is inversely, and of recurrent hyperthyroidism directly, related to remnant size. To date in this series there have been four recurrences in patients whose estimated remnants were $4,6,9$, and $12 \mathrm{~g}$. Since thyrotoxic recurrence may be diagnosed up to 20 years after operation (Hedley et al., 1970a), it is possible that others will revert to hyperthyroidism, particularly where large remnants were left at operation.

While the distribution of blood groups in the surgically treated thyrotoxic patients is the same as in the general population in this area, there is a deficit of blood group A in the hypothyroid patients and there seemed to be an excess of blood group $O$. The interpretation of this association is as yet obscure. Similarly patients with positive antithyroglobulin (tanned red cell) antibody titres seem to be more liable to develop hypothyroidism, but the association is not sufficiently definite to influence management. Though preoperative antithyroid drug therapy in this series was not standardized, it is clear that the incidence of hypothyroidism does not depend on the duration of therapy nor on the amount of drug prescribed.
While the incidence of hypothyroidism in a series of patients is closely associated with remnant size, and possibly with positive antithyroglobulin antibodies and with blood group $\mathrm{O}$, it is quite impossible to predict the future of the individual patient. Hypothyroidism can occur when a generous remnant of 10 to $12 \mathrm{~g}$ has been left, thyrotoxic recurrence with a remnant as small as $4 \mathrm{~g}$. This unpredictable response constitutes a problem in postoperative management. The records of the Research and Intelligence Unit of the Scottish Home and Health Department show that on average 350 thyrotoxic patients came to thyroidectomy annually in Scotland during the years 1965-9 compared with an average of 450 patients treated each year by radioiodine. Thus about 800 patients are subjected to destructive therapy in Scotland each year. The numbers are such that it becomes difficult to supervise adequately all these patients in routine follow-up clinics. It is for this reason that a computer-assisted register has been developed (Hedley et al., 1970b), but it will be several years before this service will become generally available.

\section{CONTINUING SUPERVISION}

For the present, continuing outpatient supervision is necessary if the not inconsiderable morbidity of hypothyroidism which follows destructive therapy is to be prevented. In this context patients treated surgically may be at an advantage over those receiving radioiodine therapy. The results published to date indicate that after radioiodine therapy the curve of incidence of hypothyroidism shows no tendency to level out. It is possible that most, if not all, patients may be found to develop hypothyroidism if they are followed for a sufficient length of time. In contrast we have good reason to believe that in surgically treated patients the probability of requiring thyroxine replacement therapy may be defined within one year of operation. Furthermore, it has been our experience that if a sufficiently high degree of suspicion of hypothyroidism is maintained during the early postoperative months the late diagnosis of hypothyroidism is rare.

Olsen et al. (1970), using slightly different criteria, found an incidence of hypothyroidism of $23 \%$ after 10 years. Of their patients who became hypothyroid, $88 \%$ were diagnosed within six months of operation and $96 \%$ within two years; they considered that the risk of developing hypothyroidism after two years was $1 \%$. On the other hand, Nofal et al. (1966) found a postoperative hypothyroid incidence of $22 \%$ after six months rising to $25 \%$ at the end of a year, with a yearly increase thereafter of $1.7 \%$ for up to 10 years.

The incidence of hypothyroidism in this series is high $(49 \%)$ but it is apparent that the incidence of hypothyroidism is influenced by remnant size. Provided a remnant of 8 to $9 \mathrm{~g}$ is left it is possible to offer a group prediction of $70 \%$ euthyroidism (Table VII) but it is not possible to predict the fate of the individual patient from remnant size alone. In contrast P.B. ${ }^{12}$ I estimations alone are of prognostic value for both the group and the individual. Where P.B. ${ }^{127} I$ values at one and four months after operation are $4 \mu \mathrm{g} / 100 \mathrm{ml}$ or more it may be assumed with reasonable confidence that these patients will remain euthyroid. Where both P.B. ${ }^{127}$ I values are less than $4 \mu \mathrm{g} / 100 \mathrm{ml}$ the risk of requiring thyroxine replacement is $75 \%$. Thus within one year it may be possible to define the ultimate thyroid status of the individual patient and to establish whether thyroxine replacement therapy will be necessary in the future. This is a matter of importance for the busy surgeon for whom a computer-assisted register may not become available for several years. Provided an adequate remnant of 8 to $9 \mathrm{~g}$ is left he can assume that some $70 \%$ of his patients will be euthyroid. Though in ideal circumstances all thyrotoxic patients subjected to surgery merit life-long supervision, special attention should be given to those whose early postoperative P.B. ${ }^{127} \mathrm{I}$ levels have been less than $4 \mu \mathrm{g} / 100 \mathrm{ml}$. 
We gratefully acknowledge the statistical help given by $\mathrm{Dr}$. Gordon Hems, and our indebtedness to Professor S. C. Frazer for the work performed in the department of chemical pathology.

\section{References}

Beahrs, O. H., and Sakulsky, S. B. (1968). Archives of Surgery, 96, 512. Beck, J. S. (1971). In Immunofluorescence Techniques in Immunopathology and Histopathology, Broadsheet 69, Association of Clinical Pathologists. London, British Medical Association.

Billewicz, W. Z., et al. (1969). Quarterly fournal of Medicine, 38, 255.

Cattell, R. B. (1949). Fournal of Clinical Endocrinology and Metabolism, 9, 999.

Crile, G., and McCullagh, E. P. (1951). Annals of Surgery, 134, 18.

Crooks, J., Murray, I. P. C., and Wayne, E. J. (1959). Quarterly fournal of Medicine, $28,211$.

Fulthorpe, A. J Roitt I. M., Doniach, D., and Couchman, K. (1961). fournal of Clinical Pathology, 14, 654.
Greig, W. R. (1965). Fournal of Clinical Endocrinology and Metabolis $m$ $25,1411$.

Hedley, A. J., Flemming, C. J., Chesters, M. I., Michie, W., and Crooks, J. (1970a). British Medical fournal, 1, 519.

Hedley, A. J., Scott, A. M., Weir, R. D., and Crooks, J. (1970b). British

Hedley, A. J., Michie, W., Duncan, T., Hems, G., and Crooks, J. (1971). In press.

Hobbs, J. R., Bayliss, R. I. S., and Maclagan, N. F. (1963). Lancet, 1, 8. Mourant, A. E., Kopec, A. C., and Domaniewska-Sobczak, K. (1958). The ABO Blood Groups, Oxford, Blackwell Scientific.

Nofal, M. M., Beierwaltes, W. H., and Patno, M. E. (1966). Fournal of the American Medical Association, 197, 605.

Olsen, W. R., Nishiyaric, R. H., and Graber, L. W. (1970). Archives of Surgery, 101, 175 .

Painter, N. S. (1960). British fournal of Surgery, 48, 291.

Riddell, V. (1962). British fournal of Surgery, 49, 465.

Werner, S. C., and Spooner, M. (1955). Bulletin of the New York Academy of Medicine, 31, 137.

Wilson, G. M. (1967). In Symposium on Thyroid Disease and Calcium Metabolism, p. 51. Edinburgh, Royal College of Physicians.

\title{
Brain Amine Concentrations after Monoamine Oxidase Inhibitor Administration
}

\author{
A. B. BEVAN JONES, C. M. B. PARE, W. J. NICHOLSON, KATHLEEN PRICE, R. S. STACEY
}

British Medical fournal, 1972, 1, 17-19

\section{Summary}

The concentrations of 5-hydroxytryptamine (5HT), noradrenaline, and dopamine were estimated post mortem in brain stem, hypothalamus, and caudate nucleus in 33 patients who had been treated with isocarboxazid, clorgyline, or tranylcypromine and 11 controls. Similar and highly significant increases in 5HT and noradrenaline concentration occurred with all three drugs. The distribution was unimodal, but about a quarter of the patients showed only a small increase in brain amines. Tranylcypromine seemed to have a significantly greater effect on dopamine in caudate nucleus and hypothalamus compared with isocarboxazid and clorgyline. In the doses used chlorpromazine did not reduce the amine concentrations. Four patients with Parkinson's syndrome had low concentrations of dopamine in caudate nucleus in spite of monoamine oxidase inhibitor administration.

\section{Introduction}

Monoamine oxidase inhibitors (M.A.O.I.s) are valuable antidepressants. However, some patients, clinically similar to those who have responded well, respond badly, and the reason for this is still obscure. Variability in the causation of the depressive symptoms or variability in drug absorption, distribution, or metabolism may all play a part but a full explanation may not be possible until there is a clear understanding of their mode of action.

\footnotetext{
Department of Psychological Medicine, St. Bartholomew's Hospital, London EC1A $7 \mathrm{BE}$

A. B. BEVAN JONES, M.B., B.CH., Registrar

C. M. B. PARE, M.D., F.R.C.P., Physician

Department of Geriatric Medicine, Brook Hospital, London S.E.18

W. J. NICHOLSON, F.R.C.P.ED., D.P.M., Consultant Physician

Department of Pharmacology and Therapeutics, St. Thomas's Hospital Medical School, London S.E.1

KATHLEEN PRICE, Laboratory Technician

R. S. STACEY, M.D., Professor
}

They are known to inhibit a number of enzyme systems. Often it is assumed that inhibition of monoamine oxidase is the most likely way in which they affect mental depression, but this is by no means certain. Recently their action as M.A.O.I.s has been complicated by the discovery of multiple forms of this enzyme (Youdim et al., 1969; Collins et al., 1970) in human brain mitochondria, each with a characteristic anatomical distribution and each with its own substrate specificity and sensitivity to inhibitors (Johnson, 1968; Fuller et al., 1970).

In 1965 we showed that it is possible to assess the effect of M.A.O.I.s on the concentration of 5-hydroxytryptamine (5HT) in human brain (Maclean et al., 1965). We have now extended this work to investigate the effect of three M.A.O.I.s on the concentrations in human brain of 5HT, noradrenaline, and dopamine. The inhibitors used were: isocarboxazid, a typical hydrazide inhibitor; tranylcypromine, a non-hydrazide with amphetamine-like actions; and clorgyline, a non-hydrazide which is reported to have a pronounced difference in its potency against two of the monoamine oxidase isoenzymes (Johnson, 1968; Hall et al., 1969).

\section{Subjects and Methods}

One of us (W.J.N.) often treats ternninally ill patients with M.A.O.I.s. Patients with illnesses regarded as "terminal," such as inoperable neoplasms or extensive cerebrovascular disease, may live for a considerable time. In such patients a depressed mood is extremely common and treatment can make the terminal period more comfortable for the patient, the relatives, and the nursing staff.

For the purposes of this investigation 33 such patients were treated with M.A.O.I.s and, unless their management contraindicated it, were continued on these drugs until death. Patients who died within 10 days of starting M.A.O.I. or who had received the drug for over 100 days before death were excluded from the series. Eleven patients received isocarboxazid, 13 clorgyline, and 9 tranylcypromine, the average age being $80 \cdot 6,85 \cdot 1$, and 85.3 years respectively. Eleven patients with an average age of 79.9 years served as controls.

Drugs.-In addition to the standard medication necessary for their medical condition the 33 patients received clorgyline (20 $\mathrm{mg}$ ), isocarboxazid (30 $\mathrm{mg}$ ), or tranylcypromine (30 $\mathrm{mg}$ ) 